\title{
KECACINGAN PADA MURID SEKOLAH DASAR DI KELURAHAN WAY MENGAKU KECAMATAN BALIK BUKIT KABUPATEN LAMPUNG BARAT
}

\author{
Wendi Bayu Utomo ${ }^{1)}$
}

\begin{abstract}
Abstrak
Kecacingan adalah penyakit yang disebabkan oleh cacing perut yang ditularkan melalui tanah. Cacing ini dapat menyebabkan menurunnya kondisi kesehatan, gizi, kecerdasan dan produktivitas penderitanya. Sehingga secara ekonomi banyak menyebabkan kerugian, karena banyak kehilangan karbohidrat dan protein serta kehilangan darah, sehingga menurunkan kualitas sumber daya manusia.

Penelitian ini bertujuan untuk mengetahui hubungan sanitasi lingkungan dan personal hygiene anak dengan kejadian kecacingan pada murid sekolah dasar di Kelurahan Way Mengaku. Penelitian menggunakan rancangan cross sectional, dilaksanakan pada bulan Mei-Juni 2017. Populasi penelitian adalah seluruh siswa sekolah dasar (kelas III dan IV). Sampel sebanyak 203 anak, dipilih dengan teknik systematic random sampling. Pengumpulan data dilakukan dengan wawancara dan observasi. Pemeriksaan parasit cacing dilakukan secara mikroskopis dengan metode apung Data dianalisis secara univariat dengan frekuensi dan proporsi, serta bivariat (menggunakan uji chi-square $\alpha=0,05$ ).

Hasil penelitian mendapatkan bahwa proporsi kecacingan pada siswa sekolah dasar di Kelurahan Way Mengaku sebesar 25,1\%. Kecacingan berhubungan signifikan dengan kepemilkan jamban ( $\mathrm{p}-$ value $<0,05$ ), jenis lantai rumah ( $\mathrm{p}$-value $<0,05)$, kepemilikan sumber air bersih ( $\mathrm{p}$-value $<0,05$ ), kebiasaan memakai alas kaki ( $\mathrm{p}$-value $<0,05)$, kebiasaan mencuci tangan ( $\mathrm{p}$-value $<0,05)$, dan kebiasaan memotong kuku (p-value $<0,05$ ). Perlu upaya peningkatan pengetahuan siswa sekolah tentang penyakit kecacingan dan pencegahannya. Peran orang tua dan guru sangat dibutuhkan dalam upaya menurunkan angka kecacingan.
\end{abstract}

Kata Kunci : Sanitasi Lingkungan, Personal Hygiene, Kejadian Kecacingan

1) Alumni Prodi D4 Kesehatan Lingkungan Poltekkes Tanjungkarang

\section{PENDAHULUAN}

Infeksi kecacingan masih menjadi masalah kesehatan pada murid sekolah dasar di Indonesia. Infeksi cacing tambang menyebabkan kehilangan darah sebanyak 16.863.000 liter darah per tahun, dan infeksi cacing cambuk sebanyak 3.372.600 liter darah per tahun (Kepmenkes RI, 2011). Lebih dari satu milyar orang terinfeksi oleh jenis cacing Soil Transmitted Helminth (STH) (Freeman et al, 2015). Menurut World Health Organization (WHO) pada tahun 2013, infeksi STH terbanyak pada kelompok usia 6-12 tahun, atau pada tahapan anak usia sekolah dasar (SD). Data WHO tahun 2015 menyebutkan bahwa lebih dari 1,5 milyar atau 24\% dari populasi dunia terinfeksi STH. Berdasarkan hasil survey pada anak SD di 175 Kabupaten/Kota pada tahun 2013, prevalensi kecacingan di Indonesia sebesar $85,9 \%$ dengan rata-rata $28,12 \%$ angka nasional.
Kecacingan merupakan salah satu masalah kesehatan masyarakat di Indonesia. Dari hasil pemeriksaan tinja pada anak sekolah dasar yang dilakukan oleh Sub Dit Diare pada tahun 20022009 di 389 sekolah dasar yang tersebar di 33 provinsi, menunjukan bahwa rata-rata prevalensi kecacingan sebesar 31,8\% (Kepmenkes RI, 2012). Menurut hasil Survey Mercy Corp di Sumatera pada tahun 2006, Provinsi Lampung tercatat sebagai peringkat kedua untuk penderita cacingan wilayah Sumatera, setelah Provinsi Riau. Dari 641 sampel yang diperiksa, sebanyak $46.64 \%$ anak menderita cacingan.

Terdapat beberapa faktor yang berhubungan dengan infeksi kecacingan, yaitu: 1) Faktor sanitasi lingkungan, yaitu kepemilikan jamban, jenis lantai rumah, dan ketersediaan air bersih; 2) Faktor personal hygiene yaitu kebiasaan memakai alas kaki, mencuci tangan sebelum makan, dan kebiasaan memotong kuku; 3) 
Faktor lain yang ikut mempengaruhi, yaitu tingkat pendidikan dan sosial ekonomi dan perilaku hidup sehat yang belum memadai (Endriani; Mifbakhudin; Sayono, 2010:23). Jenis cacing terpenting dalam infeksi kecacingan adalah cacing gelang (Askaris lumbricoides), cacing tambang (Ancylostoma duodenale dan Necator americanus) dan cacing cambuk (Trichuris trichiura) (Andaruni; Fatimah; Simangunsong, 2012:2).

Anak usia sekolah merupakan golongan masyarakat yang diharapkan dapat tumbuh sebagai sumber daya manusia yang potensial di masa yang akan datang. Sehingga harus diperhatikan dan disiapkan untuk dapat tumbuh sempurna baik fisik maupun intelektualnya (Kemenkes RI, 2012). Penelitian bertujuan mengetahui gambaran infeksi kecacingan pada siswa sekolah dasar di Kelurahan Way Mengaku Kecamatan Balik Bukit, Kabupaten Lampung Barat.

\section{METODE}

Jenis penelitian adalah deskriptif dengan rancangan cross sectional, dilakukan pada murid sekolah dasar di Kelurahan Way Mengaku Kecamatan Balik Bukit Kabupaten Lampung Barat pada bulan Mei sampai dengan bulan Juni 2017. Populasi penelitian adalah seluruh murid sekolah dasar (kelas III dan IV), sebanyak 409 orang. Sampel sebanyak 203 orang, dipilih dengan systematic random sampling. Kriteria sampel adalah tercatat sebagai murid kelas III dan IV sekolah dasar di Kelurahan Way Mengaku, bersedia menjadi subjek penelitian, dan berdomisili di Kelurahan Way Mengaku Kecamatan Balik Bukit Kabupaten Lampung Barat.

Pengumpulan data dilakukan dengan wawancara dan observasi. Pemeriksaan mikroskopis parasit cacing pada feces juga dilakukan dengan metode flotasi (Hadidjaja, Pinardi, 1994). Pemeriksaan mikroskopis dilakukan untuk mendapat informasi akurat tentang infeksi cacing perut pada subjek. Pemeriksaan dilakukan di Laboratorium Parasitologi Politeknik Kesehatan Tanjungkarang.

Data yang telah terkumpul dianalisis menggunakan perangkat SPSS. Tahap analisis univariat menggunakan frekuensi dan proporsi; bivariate menggunakan uji Chi square pada alpha $=0,05$. Data disajikan dalam bentuk tabel.

\section{HASIL}

\section{Distribusi Responden Berdasarkan Variabel Penelitian}

Sebanyak 203 orang murid sekolah dasar telah dilibatkan dalam penelitian, berasal dari empat sekolah, yaitu SD N 1 Way Mengaku, SD N 2 Way Mengaku, SD N 3 Way Mengaku, dan SD KARTIKA II-11. Hasil penelitian mendapatkan bahwa sebanyak 25,1\% murid sekolah dasar di Kelurahan Way Mengaku menderita infeksi kecacingan (Tabel 1).

Berdasarkan faktor kesehatan lingkungan (Tabel 1), sebagian besar responden tinggal di rumah yang telah memiliki jamban sehat $(72,4 \%)$, lantai rumah memenuhi syarat kesehatan $(73,4 \%)$, dan memiliki sarana air bersih yang memenuhi syarat kesehatan $(73,4 \%)$.

Faktor kebersihan diri (personal hygiene) ditanyakan dan diamati terhadap seluruh responden. Mayoritas responden $(77,3 \%)$ selalu menggunakan alas kaki pada saat bermain dan kontak dengan tanah. Mencuci tangan sebelum memegang makanan telah dilakukan oleh 69,0\% responden, dan 69,0\% memotong kuku secara rutin (Tabel 1).

Tabel 1. Distribusi Variabel Penelitian

\begin{tabular}{lcc}
\hline Varibel Penelitian & $\mathrm{n}$ & $\%$ \\
\hline Kecacingan & & \\
$\quad$ Kecacingan & 51 & 25,1 \\
$\quad$ Tidak kecacingan & 152 & 74,9 \\
Kepemilikan jamban sehat & & \\
$\quad$ Memenuhi syarat & 147 & 72,4 \\
$\quad$ Tidak memenuhi syarat & 56 & 27,6 \\
Lantai rumah & & \\
$\quad$ Memenuhi syarat & 149 & 73,4 \\
$\quad$ Tidak memenuhi syarat & 54 & 26,6 \\
Kepemilikan SAB & & \\
$\quad$ Memenuhi syarat & 149 & 73,4 \\
$\quad$ Tidak memenuhi syarat & 54 & 26,6 \\
Mengunakan alas kaki & & \\
$\quad$ Baik & 157 & 77,3 \\
$\quad$ Tidak baik & 46 & 22,7 \\
Mencuci tangan & & \\
$\quad$ Baik & 140 & 69,0 \\
$\quad$ Tidak baik & 63 & 31,0 \\
Memotong kuku & & \\
$\quad$ Baik & 140 & 69,0 \\
Tidak baik & 63 & 31,0 \\
\hline
\end{tabular}




\section{Hubungan Faktor Kesehatan Lingkungan dan Kecacingan}

Penelitian mendapatkan bahwa anak sekolah dasar yang tinggal di rumah belum memiliki jamban sehat sebanyak 27,6\%. Separuh dari responden $(50 \%)$ yang tinggal di rumah dengan kondisi jamban tidak sehat, menderita infeksi kecacingan (Tabel 2). Pada kelompok yang memiliki jamban sehat, proporsi kecacingan sebesar 15,6\%. Hasil analisis statistik menunjukkan hubungan yang signifikan antara kepemilikan jamban sehat dengan kecacingan (p-value $<0,05$ ).

Pada Tabel 2 terlihat bahwa proporsi anak sekolah dasar yang tinggal di rumah dengan lantai tidak memenuhi syarat kesehatan dan menderita kecacingan sebesar 50\%. Sementara yang tinggal di rumah dengan lantai memenuhi syarat sebesar $16,1 \%$. Analisis statistik membuktikan hubungan yang bermakna antara kondisi lantai rumah dengan kecacingan ( $\mathrm{p}$ value $<0,05)$.

Mayoritas anak sekolah dasar yang menderita kecacingan $(55,6 \%)$, tinggal di rumah dengan sumber air bersih yang tidak memenuhi syarat kesehatan. Pada kelompok yang sehat, sebanyak $85,9 \%$ tinggal di rumah dengan sumber air bersih yang memenuhi syarat kesehatan. Hasil analisis Chi square menunjukkan hubungan bermakna antara kepemilikan sumber air bersih dengan kecacingan ( $\mathrm{p}$-value $<0,05$ ).

\section{Hubungan Personal Higiene dan Kecacingan}

Pada Tabel 1 disampaikan bahwa mayoritas anak sekolah $(77,3 \%)$ menggunakan alas kaki pada saat bermain dan kontak dengan tanah. Hasil uji hubungan (Tabel 2) mendapatkan bahwa lebih dari separuh anak sekolah dasar yang menderita kecacingan (54,3\%), tidak menggunakan alas kaki pada saat bermain dan kontak dengan tanah. Sedangkan pada kelompok yang sehat, sebagian besar menggunakan alas kaki (83,4\%). Analisis statistik menunjukkan hubungan yang bermakna pada kedua variabel ( $\mathrm{p}$-value $<0,05)$.

Pada Tabel 2 terlihat bahwa proporsi anak sekolah dasar yang tidak mencuci tangan sebelum memegang makanan dan menderita kecacingan sebesar 55,6\%. Sementara yang mencuci tangan sebelum memegang makanan dan menderita kecacingan sebesar 11,4\%. Analisis statistik membuktikan hubungan yang bermakna antara kebiasaan mencuci tangan dengan kecacingan ( $\mathrm{p}$-value $<0,05$ ).

Sebagian besar anak sekolah dasar yang menderita kecacingan (54,0\%), memiliki kebiasaan memotong kuku secara teratur. Pada kelompok yang sehat, sebanyak $87,9 \%$ memiliki kuku pendek dan memotong kuku secara teratur. Hasil analisis Chi square menunjukkan hubungan bermakna antara kebiasaan memotong kuku dengan kecacingan (p-value $<0,05$ ).

Tabel 2. Hasil Analisis Chi-Square

\begin{tabular}{|c|c|c|c|c|c|}
\hline \multirow{2}{*}{ Variabel } & \multicolumn{2}{|c|}{ Kecacingan } & \multicolumn{2}{|c|}{ Tidak kecacingan } & \multirow{2}{*}{ p-value } \\
\hline & $\mathrm{n}$ & $\%$ & $\mathrm{n}$ & $\%$ & \\
\hline \multicolumn{6}{|l|}{ Kepemilikan jamban sehat } \\
\hline Tidak memenuhi syarat & 28 & 50,0 & 28 & 50,0 & \multirow{2}{*}{0,0001} \\
\hline Memenuhi syarat & 23 & 15,6 & 124 & 84,4 & \\
\hline \multicolumn{6}{|l|}{ Lantai rumah } \\
\hline Tidak memenuhi syarat & 27 & 50,0 & 27 & 50,0 & \multirow{2}{*}{0,0001} \\
\hline Memenuhi syarat & 24 & 16,1 & 125 & 83,9 & \\
\hline \multicolumn{6}{|l|}{ Kepemilikan SAB } \\
\hline Tidak memenuhi syarat & 30 & 55,6 & 24 & 44,4 & \multirow{2}{*}{0,0001} \\
\hline Memenuhi syarat & 21 & 14,1 & 128 & 85,9 & \\
\hline \multicolumn{6}{|l|}{ Mengunakan alas kaki } \\
\hline Tidak baik & 25 & 54,3 & 21 & 45,7 & \multirow{2}{*}{0,000046} \\
\hline Baik & 26 & 16,6 & 131 & 83,4 & \\
\hline \multicolumn{6}{|l|}{ Mencuci tangan } \\
\hline Tidak baik & 35 & 55,6 & 28 & 44,4 & \multirow{2}{*}{0,0001} \\
\hline Baik & 16 & 11,4 & 124 & 88,6 & \\
\hline \multicolumn{6}{|l|}{ Memotong kuku } \\
\hline Tidak baik & 34 & 54,0 & 29 & 46,0 & \multirow{2}{*}{0,0001} \\
\hline Baik & 17 & 12,1 & 123 & 87,9 & \\
\hline
\end{tabular}




\section{PEMBAHASAN}

Hasil dari penelitian ini menunjukan bahwa dari 203 anak sekolah dasar yang diperiksa, ditemukan sebanyak $25,1 \%$ menderita kecacingan. Hasil penelitian ini juga sejalan dengan Jalaludin (2009) yang mendapatkan angka kecacingan sebesar $52,7 \%$ pada murid sekolah dasar di Kecamatan Blang Mangat. Infeksi kecacingan banyak ditemui pada anakanak usia sekolah dasar karena aktifitas meraka yang lebih banyak berhubungan dengan tanah. Sebagai parasit, selain mengambil nutrisi dari dalam usus anak, cacing juga akan merusak dinding usus sehingga mengganggu penyerapan zat-zat gizi tersebut (Enriani, dkk, 2011). Anakanak yang terinfeksi cacing biasanya mengalami gejala lesu, pucat akibat anemia, berat bandan menurun, tidak bergairah, konsentrasi belajar kurang dan kadang disertai batuk-batuk (Nadesul, 1997).

Hasil analisis statistik menunjukkan hubungan yang bermakna antara kepemilikan jamban sehat dengan kecacingan (p-value<0,05). Separuh dari anak sekolah dasar yang tinggal di rumah dengan jamban tidak sehat, menderita infeksi kecacingan. Hasil penelitian ini sesuai Evi Yulianto (2007) yang menyatakan adanya hubungan antara kepemilkan jamban dengan kejadian kecacingan.

Jamban sehat adalah jamban yang mampu mengisolasi tinja manusia sehingga tidak kontak dengan air tanah, serangga, dan tikus. Jamban sehat dapat dibuat dengan bahan sederhana, murah, dan tersedia di daerah setempat, sesuai dengan kemampuan masyarakat. Menurut Kemenkes RI (1999), syarat jamban sehat yang harus dipenuhi adalah: 1) tidak dapat dijangkau oleh serangga dan tikus atau hewan lainnya; 2) tidak mencemari sumber air bersih; 3) tidak menimbulkan bau; 4) tidak menimbulkan kecelakaan bagi penggunanya.

Hubungan bermakna juga ditemukan antara kondisi lantai rumah dengan kecacingan (p-value<0,05). Separuh dari anak sekolah dasar yang tinggal di rumah dengan lantai tidak memenuhi syarat kesehatan menderita kecacingan. Sementara yang tinggal di rumah dengan lantai memenuhi syarat kesehatan, hanya sebesar $16,1 \%$. Hasil penelitian sesuai dengan penelitian Yulianto (2007) yang menemukan hubungan bermakna antara kondisi lantai rumah dengan kejadian kecacingan.
Menurut Kemenkes RI (1999), rumah sehat merupakan bangunan rumah yang lantainya kedap air, bersih dan mudah dibersihkan. Lantai rumah dapat terbuat dari ubin dan plesteran. Sedangkan menurut Soekidjo Notoatmodjo (1997) syarat-syarat rumah yang sehat jenis lantai yang tidak berdebu pada musim kemarau dan tidak basah pada musim penghujan. Lantai rumah dapat terbuat dari ubin atau semen, kayu.

Komponen rumah lainnya yang berhubungan dengan kecacingan pada murud sekolah dasar adalah kepemilikan sarana air bersih. Hasil penelitian mendapatkan sebanyak 55,6\% anak sekolah dasar yang tinggal di rumah dengan sumber air bersih yang tidak memenuhi syarat kesehatan, menderita kecacingan. Hasil analisis Chi square menunjukkan hubungan bermakna antara kepemilikan sumber air bersih dengan kecacingan ( $p$-value $<0,05$ ).

Air digunakan untuk sehari-hari seperti memasak, minum, mandi, mencuci, dan lainlain. Secara umum, permasalahan yang terkait dengan air bersih adalah sarana yang tidak sehat, pencemaran sumber air akibat konstruksi yang tidak baik, serta perilaku dalam pengelolaan sumber air bersih. Menurut Kemenkes RI (1999), jika sumber air tidak dikelola dengan baik dapat menimbulkan beberapa penyakit, salah satunya adalah kecacingan. Kecacingan dapat ditularkan melalui air yang telah tercemar tinja manusia yang mengandung telur cacing. Hasil penelitian ini sesuai dengan penelitian Yulianto (2007) di Kecamatan Tembalang yang juga menemukan hubungan bermakna antara kepemilikan sarana air bersih dengan kecacingan.

Kebersihan diri (personal hygiene) menjadi salah faktor yang berhubungan erat dengan infeksi kecacingan. Hasil penelitian mendapatkan hubungan yang signifikan (pvalue $<0,05$ ), antara kecacingan dengan kebiasaan memakai alas kaki, mencuci tangan, dan memotong kuku secara teratur. Pada kelompok yang menderita kecacingan, sebanyak $54,3 \%$ tidak memiliki kebiasaan memakai alas kaki pada saat bermain atau kontak dengan tanah, 55,6\% tidak memiliki kebiasaan mencuci tangan sebelum memegang makanan, dan 54,0\% tidak memotong kuku secara teratur.

Hasil penelitian ini sesuai dengan Jalaluddin (2009) yang menyampaikan adanya hubungan yang bermakna antara kebiasaan memakai alas kaki dengan kejadian kecacingan. Anak usia sekolah merupakan golongan yang sering 
berhubungan dengan tanah. Yulianto (2007) dan Enriani, dkk, (2011) juga menyampaikan adanya hubungan yang kuat antara kecacingan dengan kebiasaan mencuci tangan dan kebersihan kuku. Menurut Kemenkes RI (2011, 2012), memelihara kebersihan diri dengan baik seperti memotong kuku, mencuci tangan sebelum makan, dan menggunakan alas kaki, penting dilakukan untuk mencegah masuknya parasit cacing ke dalam tubuh. Kuku yang panjang dan tangan yang kotor, menjadi perantara masuknya telur infektif ke dalam tubuh manusia.

Berdasarkan hasil penelitian, maka upaya pengendalian kecacingan harus segera dilakukan. Mengingat dampak jangka panjang kecacingan adalah malnutrisi sehingga terganggu perkembangan kognitif pada anak. Tiga langkah utama yang dilakukan dalam pengendalian kecacingan adalah: 1) Melakukan pengobatan untuk membasmi parasit dalam tubuh; 2) Perbaikan sarana sanitasi terutama meningkatkan kepemilikan jamban sehat dan sumber air minum. Mengingat masuknya parasit ke tubuh manusia dalam bentuk telur infektif dan larva infektif yang dikeluarkan bersama feces; 3) Meningkatkan kebersihan diri (personal hygiene). Pada bagian ini dibutuhkan peran orang tua, guru, dan petugas kesehatan untuk meningkatkan pengetahuan kesehatan anak-anak, sehingga mampu menjaga kebersihan dan kesehatannya.

\section{KESIMPULAN}

Hasil penelitian mendapatkan bahwa proporsi kecacingan pada siswa sekolah dasar di Kelurahan Way Mengaku sebesar 25,1\%. Faktor kesehatan lingkungan yang berhubungan signifikan dengan kecacingan adalah kepemilkan jamban (p-value $<0,05)$, jenis lantai rumah (p-value $<0,05$ ), kepemilikan sumber air bersih ( $p$-value<0,05). Sedangkan faktor kebersihan diri berhubungan signifikan dengan kecacingan adalah kebiasaan memakai alas kaki (p-value $<0,05$ ), kebiasaan mencuci tangan (p-value $<0,05$ ), dan kebiasaan memotong kuku (p-value $<0,05)$. Perlu upaya serius untuk mengendalikan infeksi kecacingan pada murid sekolah, mengingat dampaknya terhadap malnutrisi dan terganggunya perkembangan kognitif. Peran orang tua, guru dan tenaga kesehatan sangat dibutuhkan untuk meningkatkan pengetahuan kesehatan anak usia sekolah.

\section{DAFTAR PUSTAKA}

Andaruni; Fatimah; Simangunsong, 2012, Gambaran Faktor-faktor Penyebab Infeksi Cacingan pada Anak di SDN 01 Pasir Langu Cisarua, Fakultas Ilmu Keperawatan Universitas Padjajaran, Bandung, Jawa Barat.

Enriani, Mifbakhudin, Sayono, 2010. Beberapa Faktor Yang Berhubungan Dengan Kejadian Kecacingan Pada Anak Usia 1-4 Tahun. Jurnal Kesehatan Masyarakat Indonesia Volume 7(1)2011. https://jurnal.unimus.ac.id/index.php /jkmi/article/view/585

Hadidjaja, Pinardi, 1994. Penuntun Laboratorium Parasitologi Kedokteran, EGC

Jalaludin, 2009, Pengaruh Sanitasi Lingkungan, Personal Hygiene dan Karakteristik Anak Terhadap Infeksi Kecacingan pada Murid Sekolah Dasar di Kecamatan Blangmangat Kota Lhoksumawe, Pasca Sarjana Universitas Sumatra Utara, Medan.

Kemenkes RI, 1999, Keputusan Menteri Kesehatan Republik Indonesia Nomor 29/Menkes/SK/VII/1999, Tentang Persyaratan Kesehatan Perumahan

Kemenkes RI, 2010, Penyakit Kecacingan Masih Dianggap Sepele, http//www.depkes.go.id, diakses 12 januari 2017.

Kemenkes RI, 2011, Materi Pelatihan Dokter Kecil, Kementerian Kesehatan, Jakarta..

Kemenkes RI, 2012. Keputusan Menteri Kesehatan RI Nomor : 424 / MENKES / SK / VI, 2012, Pedoman Pengendalian Cacingan, Kementerian Kesehatan, Jakarta.

Nadesul, H, 1997, Infeksi Cacing, Rineka Cipta, Jakarta.

Notoatmodjo, S, 2011, Ilmu Kesehatan Masyarakat Prinsip-Prinsip dasar, PT. Rineka Cipta, Jakarta.

Yulianto, E, 2007, Hubungan Hygiene Sanitasi dengan Kejadian Penyakit

Cacingan pada Murid Sekolah Dasar Negri Rowosari 01 Kecamatan Tembalang, Fakultas Ilmu Kesehatan Masyarakat Universitas Negeri Semarang, Semarang. 